\title{
Pengaruh Pertambangan Pasir Terhadap Erosi dan Sedimentasi Sungai (Studi Kasus Di Desa Tanjung Alam Kecamatan Sei Dadap Kabupaten Asahan)
}

\author{
The Effect of Sand Mining on River Erosion and Sedimentation \\ (Case Study in Tanjung Alam Village, Sei Dadap District, Asahan Regency)
}

Muchlish, I.A. Faisyal, S. Sunarsih*

Jurusan Teknik Lingkungan, Institut Sains \& Teknologi AKPRIND Yogyakarta 55222

\section{Artikel histori : \\ Diterima 15 Juli 2021 \\ Diterima dalam revisi 29 September 2021 Diterima 30 September 202 Online 1 November 2021}

\begin{abstract}
ABSTRAK: Penambangan pasir di desa Tanjung Alam Kecamatan Sei Dadap Kabupaten Asa yang dilakukan dengan mesin sedot diduga dapat memberikan dampak negatif terha lingkungan. Penelitian ini bertujuan untuk melihat pengaruh pertambangan pasir terhadap e dan sedimentasi di sungai Asahan di Desa Tanjung Alam Kecamatan Sei Dadap Kabupi Asahan Provinsi Sumatera Utara. Tahapan analisis dimulai dengan pengukuran profil sun pengukuran kecepatan aliran, pengukuran debit sungai, pengukuran konsentrasi sedin pengukuran curah hujan, pengukuran kemiringan lereng dan perhitungan perkiraan laju er Untuk menghitung perkiraan laju erosi pada penelitian ini menggunakan metode USLE dan ur menghitung muatan sedimen menggunakan SNI 3414 : 2008 dengan teknik depth-integrating Berdasarkan hasil perhitungan diketahui bahwa aktivitas tambang pasir menyebabkan penyempitan profil sungai, mempercepat aliran sungai, memperbesar debit sungai sehingga meningkatkan laju erosi, dan sedimentasi. Nilai muatan sedimen tertinggi pada titik 5 yang terletak di hilir penambangan 1 dan 2 dengan nilai sebesar 2922,48 ton/hari. Sedangkan perkiraan laju erosi tertinggi pada titik 5 dengan nilai sebesar 125,9 ton/ha/tahun yang masuk dalam kategori berat. Pengukuran pada setiap titik sampling membuktikan bahwa aktivitas penambangan pasir memberikan pengaruh tinggi terhadap peningkatan laju erosi dan sedimentasi di sungai.
\end{abstract}

Kata Kunci: Tambang pasir, sedimentasi, nilai laju erosi

\begin{abstract}
Sand mining in Tanjung Alam Village, Sei Dadap District, Asahan Regenc which is carried out with a suction machine is thought to have a negative impact on t] environment. This study aims to examine the effect of sand mining on erosion and sedimentatic in that river. The analysis steps begins with measuring the river profile, measuring flow velocit measuring river discharge, measuring sediment concentration, measuring rainfall, measurir slope and calculating the estimated rate of erosion. To calculate the estimated erosion rate in th study using the USLE method and to calculate the sediment load using SNI 3414: 2008 with t] depth-integrating technique. Based on the calculation results, it is known that sand minir activity causes narrowing of the river profile, accelerates river flow, increases river discharge that it increases the rate of erosion, and sedimentation. The highest sediment load value is point 5 which is located downstream of mining 1 and 2 with a value of 2922.48 tons/day. Whi the highest estimated erosion rate is at point 5 with a value of 125.9 tons/ha/year which included in the heavy category. Measurements at each sampling point prove that sand minir activities have a high impact on increasing the rate of erosion and sedimentation in rivers
\end{abstract}

Key words: sand mining, sedimentation, erosion rate value

\section{Pendahuluan (Introduction)}

Sungai dapat diartikan sebagai aliran terbuka dengan ukuran geometrik (tampak lintang, profil memanjang dan kemiringan lembah) berubah seiring waktu, tergantung pada debit, material dasar dan tebing, serta jumlah dan jenis sedimen yang terangkut oleh air (Putra, 2014). Proses pembentukan sungai berasal dari mata air yang mengalir di atas permukaan bumi. Selanjutnya aliran air akan bertambah besar seiring dengan

\footnotetext{
* Corresponding Authir

Email srisunarsih@akprind.ac.id
} 
terjadinya hujan. Limpasan air hujan yang tidak dapat diserap bumi akan ikut mengalir ke dalam sungai. Aliran sungai dari hulu menuju hilir secara berangsur-angsur menyatu dengan banyak anak sungai lainnya Penggabungan ini membuat tubuh sungai menjadi semakin besar (Junaidi, 2014).

Peraturan Pemerintah RI No. 38 tahun 2011, mengatakan yang disebut dengan daerah aliran sungai (DAS) adalah suatu wilayah daratan yang merupakan satu kesatuan dengan sungai dan anak-anak sungainya, yang berfungsi menampung, menyimpan, dan mengalirkan air yang berasal dari curah hujan ke laut secara alami. Batas DAS di darat merupakan pemisah topografis dan batas di laut sampai dengan daerah perairan yang masih terpengaruh aktivitas daratan.

Salah satu permasalahan yang lazim ditemukan terjadi pada sungai adalah terjadinya proses sedimentasi. Pergerakan sedimen memiliki arti sangat penting terhadap sungai (Syarifudin, 2017). Pengendapan sedimen dalam besaran yang tepat serta ukuran butiran yang sesuai dapat menciptakan habitat bagi kehidupan akuatik. Pengendapan sedimen yang teratur dapat membangun bar untuk habitat akuatik. Ukuran butiran sedimen yang sesuai diperlukan misalnya untuk habitat pemijahan ikan. Proses pemijahan akan banyak mengaami kendala jika ukuran sedimen yang terlalu halus, karena dapat menyebabkan telur dan makhluk bentik lainnya tercekik (Anonim, 2021).

Selain mendukung terbentuknya habitat yang sesuai untuk kehidupan akuatik, pengendapan sedimen juga memberi manfaat secara langsung maupun tak langsung. Salah satu manfaat dari pergerakan sedimen ini adalah untuk menyediakan nutrisi bagi tanaman air, serta vegetasi di ekosistem dekat pantai seperti dataran banjir dan rawa-rawa (Anonim, 2021).

Jumlah deposisi sedimen yang terlalu banyak dapat mengubur habitat dan mengubah jalur aliran air. Sedimen tersuspensi yang berlebihan cenderung berdampak negatif pada kehidupan akuatik. Sedimen ini dapat menghalangi cahaya matahari untuk mencapai vegetasi yang hidup di bawah permukaan air. Akibatnya, terjadi penurunan laju fotosintesis dan menurunkan kadar oksigen terlarut. Permasalahan lain yang timbul akibat berlebihnya sedimen yakni dapat tersumbatnya insang ikan dan merusak organ lain. Konsentrasi sedimen yang tinggi secara terus-menerus dapat mendorong spesies yang lebih sensitif untuk meninggalkan daerah tersebut, sementara organisme yang toleran terhadap lumpur bergerak masuk. Berlebihnya muatan sedimen di perairan juga dapat menyebabkan kualitas air yang buruk. Selain menyebabkan keruh, sedimen dapat menaikkan temperatur air (karena sedimen memiliki kapasitas menyerap panas lebih tinggi dibanding air. Jika temperatur air meningkat, maka nilai oksigen terlarut akan menurun (kaidah Hukum Henry). Dampak lain yang ditimbulkan oleh berlebihnya sedimen adalah terjadinya pertumbuhan alga secara pesat karena berlebihnya nutrien, dan penumpukan endapan (Anonim, 2021).

Tidak hanya pengendapan sedimen terlalu banyak yang dapat menimbulkan masalah pada lingkungan. Pengendapan sedimen yang sedikit juga dapat berdampak merugikan serta menurunkan kualitas ekosistem. Kekurangan sedimen biasanya disebabkan oleh penambahan struktur buatan manusia seperti bendungan. Kekurangan transportasi dan pengendapan sedimen akan menghalangi pembentukan habitat baru. Kekurangan pengendapan sedimen juga menyebabkan sungai kekurangan nutrien (yang biasanya ikut terbawa oleh sedimen). Hal ini akan mengganggu vegetasi yang hidup di bawah permukaan air. Dalam taraf tertentu, kekurangan sedimen dapat mengubah ekosistem hingga spesies asli tidak dapat bertahan hidup (Anonim, 2021).

Selain berpengaruh pada kehidupan akuatik, berkurangnya transport dan pengendapan sedimen dapat mempengaruhi perubahan fisik di lingkungan. Di hilir sungai yang dibendung, zona riparian dan lahan basah menurun akibat hilangnya sedimen. Erosi di arah hilir penghalang (misal bendungan) sering terjadi karena aliran air kekurangan muatan sedimen. Air akan mengambil sedimen baru dari dasar dan tepi aliran (Anonim, 2021).

Permasalahan lain yang dapat timbul dari sedimentasi adalah komponenn .yang terkontaminasi bahan berbahaya dan beracun (B3). Ini dapat terjadi jika sedimen mengakumulasi bahan dasar sungai yang mengandung zat B3. Bahan B3 dapat merugikan kesehatan perairan, manusia maupun lingkungan. Kontaminan B3 sering berasal dari polusi sumber titik (misalnya air limbah industri). Namun kontaminan B3 ini juga dapat berasal dari air limpasan yang masuk ke aliran sungai. Air limpasan dapat terkontaminasi oleh kegiatan pertambangan, air lindi tempat pembuangan akhir sampah perkotaan, ceceran bahan kimia dari berbagai kegiatan maupun endapan dari atmosfer yang mengandung polutan udara (Anonim, 2021).

Kontaminan-kontaminan B3 biasanya memiliki waktu paruh yang panjang (terdegradasi sangat lambat) sehingga dapat menimbulkan dampak negatip terhadap lingkungan dalam jangka waktu yang lama.. Kontaminan yang paling banyak menimbulkan ermasalah baik pada sedimen dasar maupun sedimen tersuspensi adalah logam dan senyawa-senyawa yang tergolong racun bioakumulasi persisten (PBT), seperti pestisida dan metil merkuri (Anonim, 2021).

Mencermati banyaknya dampak buruk yang dapat terjadi yang berkaitan dengan penegendapan sedimen, maka pengaruh suatu kegiatan terhadap perubahan debit sedimen perlu diteliti dengan seksama

DAS Asahan terletak di Provinsi Sumatera Utara. DAS Asahan mencakup Danau Toba yang menjadi hulunya berikut Sungai Asahan sebagai outlet sungai utamanya. Panjang sungai Asahan $147 \mathrm{~km}$ dengan enam buah anak sungai utama. Luas dari DAS Asahan mencapai $3.741 \mathrm{~km}^{2}$ dengan hulu berasal dari Danau Toba dan mengalirkan sungai hingga ke Selat Malaka. 
Rata-rata curah hujan yang ada di DAS Asahan yaitu sekitar $2.112 \mathrm{~mm}$ per tahun. Kota utama yang dilingkupi oleh DAS Asahan diantaranya Parapat, Porsea, Balige, Kisaran dan Tanjung Balai. Titik ketinggian tertinggi di DAS Asahan yaitu Gunung Dolok Sibutan dengan tinggi 2.457 mdpl sedangkan yang terendah terdapat di Tanjung Jumpul dengan ketinggian 0 mdpl (Kusumawardani, 2009).

Seperti DAS lain, DAS Asahan juga memiliki berbagai permasalahan misalnya erosi, pencemaran yang berasal dari aktivitas perusahaan, pembalakan sungai serta pembangunan tempat tinggal. Beberapa kegiatan ini terindikasi tidak memperhatikan kelestarian dan daya dukung sungai

Proses pengangkutan dan pengendapan sedimen dapat mengubah topografi dasar sungai. Endapan sedimen ini merupakan faktor utama yang membatasi pengembangan dan pengelolaan sungai. Proses sedimentasi akan berdampak signifikan terhadap umur operasi sungai, kapasitas pengendalian banjir dan transportasi (Syarifudin, 2017)

Kualitas dan kuantitas sungai sangat dipengaruhi oleh perubahan-perubahan iklim sesuai dengan perkembangan lingkungan yang terjadi dan pola hidup masyarakat sekitar sungai. Wardhana (2004) menjelaskan bahwa baik buruknya suatu perairan bisa dipengaruhi oleh kegiatan di sekitarnya. Seringkali kegiatan yang ada dapat menurunkan kualitas air dan pada akhirnya akan mengganggu kehidupan biota akuatik. Selain itu, upaya pemanfaatan sumber daya alam perairan juga turut mempengaruhi eksistensi komponen ekosistem perairan baik secara struktural maupun fungsional.

Salah satu kegiatan masyarakat sekitar sungai yang dapat menurukan tingkat kualitas dan kuantitas sungai adalah aktivitas penambangan pasir.

Menurut Suhartini (2006) pasir sebagai sumber daya alam merupakan bagian yang tidak terpisahkan dari suatu ekosistem. Pasir sungai merupakan lingkungan tempat berlangsungnya hubungan timbal balik antara makhluk hidup dan faktor-faktor alam, antara makhluk hidup yang satu dan yang lain serta antara faktor alam yang satu dengan lainnya. Lingkungan hidup sebagai media timbal balik makhluk hidup dengan faktor-faktor alam memiliki berbagai keadaan dan hubungan yang secara bersama-sama membentuk struktur dasar ekosistem sebagai suatu kesatuan yang mantap. Hubungan timbal balik tersebut merupakan mata rantai atau siklus penting yang menentukan daya dukung lingkungan hidup bagi pembangunan.

Pengaruh pertambangan pasir terhadap sedimentasi sungai dan laju erosi sungai pernah diteliti oleh Fatmawati (2016). Berdasar kajiannya terhadap sedimentasi aliran sungai Batang Sinamar bagian tengah di Kenagarian Koto Tuo Kecamatan Harau Kabupaten Limah Puluh Kota, terungkap bahwa beban endapan sedimen (QS) pada musim kemarau sebesar 26,12305 ton/th. Terungkap pula bahwa besarnya sedimentasi di aliran Sungai Batang Sinamar mengalami peningkatan dari musim kemarau ke musim hujan. Dari fakta tersebut dapat diartikan bahwa sedimentasi meningkat seiring terjadinya peningkatan debit sungai, dan menyebabkan kerusakan pada aliran sungai.

Dyahwanti (2007) mengkaji dampak lingkungan kegiatan penambangan pasir pada daerah Sabuk Hijau gunung Sumbing di Kabupaten Temanggung, Jawa Tengah. Diduga aktivitas tersebut menyebabkan terjadinya erosi di lokasi penambangan dengan tingkat bahaya erosi termasuk berat dan sangat berat. Hal ini berakibat meningkatkan sedimentasi pada Sungai Sigandul.

Sabrina (2018) mengkaji sedimentasi pada muara sungai Batang Arau Kota Padang. Hasil kajian angkutan sedimen dengan metode Engelund \& Hansen menunjukkan ketebalan endapan di pelabuhan Muara Batang Arau sebesar 21,64 cm per tahun.

Tamrin (2018) melakukan analisis pengaruh kegiatan penambangan pasir - batu terhadap erosi di sekitar sungai Indragiri. Hasil kajian menunjukkan bahwa penambangan pasir - batu di Desa Pasir Keranji menyebabkan badan sungai semakin melebar akibat erosi dan kedalaman sungai semakin dangkal akibat pengendapan.

Berbagai penelitian yang pernah dilakukan menunjukkan bahwa ada pengaruh berbagai aktivitas penambangan pasir di sungai terhadap sedimentasi sungai. Hal ini mendorong dilakukannya analisis lebih mendalam mengenai dampak pertambangan pasir yang marak terjadi di Desa Tanjung Alam Kecamatan Sei Dadap Kabupaten Asahan Provinsi Sumatera Utara terhadap erosi, sedimentasi, dan pendangkalan sungai

\section{Metode Penelitian}

Obyek penelitian ini adalah tingkat erosi dan sedimentasi di DAS Asahan Desa Tanjung Alam Kecamatan Sei Dadap Kabupaten Asahan Provinsi Sumatera Utara. Penelitian dilaksanakan pada tanggal 1 Desember 2020 sampai dengan Januari 2021. Titik sampling dipilih di sekitar Desa Tanjung Alam Kecamatan Sei Dadap Kabupaten Asahan Provinsi Sumatera Utara. Dalam hal ini titik sampling 1 dipilih 1 $\mathrm{km}$ sebelum kegiatan penambangan pasir (ke arah hulu) sebagai zona yang tidak terpengaruh penambangan, titik ke 2 berjarak $100 \mathrm{~m}$ sebelum penambangan yang pertama (ke arah hulu). Titik ke 3 dan ke 4 berada diantara 2 pertambangan pasir, sedangkan titik ke 5 dipilih $100 \mathrm{~m}$ setelah $\mathrm{f}$ pertambangan yang ke 2 .

Untuk mengetahui tingkat erosi diperlukan data debit sungai dari pengukuran profil dan kecepatan aliran sungai serta konsentrasi sedimen.

Penentuan profil sungai dilakukan dengan membagi lebar sungai menjadi 10 bagian dan masingmasing diukur kedalamannya. Luas profil sungai dihitung dari penjumlahan luas bagian-bagian tersebut.

Pengukuran kecepatan aliran (mengacu pada dokumen SNI 8066 : 2015. Pengukuran dilakukan pada 
aliran sungai yang lurus, sepanjang 50 meter. Aliran sepanjang 50 meter tersebut dibagi menjadi 5 bagian yang sama panjang. Masing- masing penampang diberi batas agar pada saat pelampung melampaui penampang dapat jelas terlihat dan pengukuran waktu tempuhnya lebih akurat. Pelampung permukaan dilepas mulai dari penampang I dan seterusnya dan dicatat waktu tempuh. Kecepatan aliran sungai merupakan jarak tempuh dibagi rerata waktu tempuh.

Pengambilan sampil air sungai didasarkan pada metode sampling sedimen dmenurut SNI 3414 : 2008 dengan teknik depth-integrating. Sedangkan penentuan konsentrasi sedimen dilakukan di laboratorium. Sampel air lalu dalam volume tertentu disaring dengan menggunakan kertas saring Whatman berukuran pori $0,45 \mathrm{~mm}$. Kertas saring kemudian dikeringkan di dalam oven sampai berat konstan. Konsentrasi sedimen dapat diketahui dari berat sedimen dibagi volume air sungai (dinyatakan dalam $\mathrm{mg} / \mathrm{L}$ )

Besarnya tingkat sdimentasi dalam setahun dihitung dengan rumuas Qs $=0,0864 \times$ Cs x Qw dengan Qs : debit sedimen (ton/hari)

Cs : konsentrasi sedimen dalam $\mathrm{mg} / \mathrm{L}$ Qw : debit sungai $\left(\mathrm{m}^{3} / \mathrm{dt}\right)$.

\section{3.. Hasil dan pembahasan}

\subsection{Dampak pertambangan pasir terhadap profil sungai}

Hasil pengukuran dan perhitungan menunjukkan penurunan profil sungai dari arah hulu ke hilir seperti tampak pada gambar 1 . Titik 1 pada bagian hulu yang relatif jauh dari pertambangan dan titik 2 yang berjarak $100 \mathrm{~m}$ sebelum area pertambangan menunjukkan profil yang hampir tidak berubah. Sedangkan titik 3 sampai titik 5 yang sudah melewati pertambangan menunjukkan penurunan profil sungai.

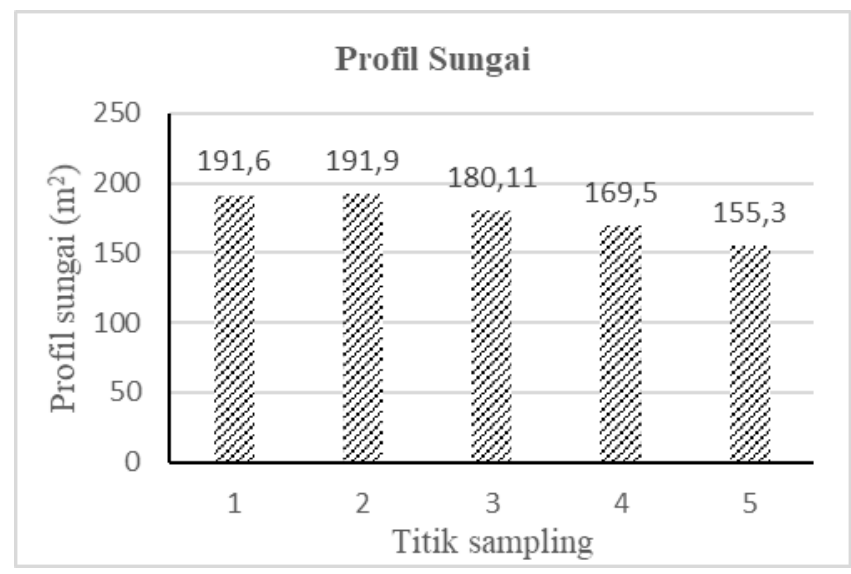

Gambar 1. Pengukuran profil sungai

Profil sungai yang mengecil ditandai dari perubahan lebar sungai yang berkurang (menjadi lebih sempit) dan pendangkalan sungai. Hal ini terjadi akibat proses erosi dan sedimentasi.. Penyedotan pasir yang dilakukan dalam proses penambangan akan menyebabkan air ikut tersedot. Ketika pasirnya dikumpulkan di tepian sungai, air yang terikut akan mengalir kembali ke sungai dengan membawa partikel- partikel tanah. Proses ini terus-menerus berlangsung dalam jangka waktu yang lama. Proses tersebut yang menjadi salah satu faktor tingginya konsentrasi sedimen dalam air sehingga mempengaruhi perubahan profil sungai. Selanjutnya perubahan profil sungai akan berpengaruh pada fungsi sungai, yang berupa penurunan pada kemampuan sungai dalam menampung air larian

\subsection{Dampak pertambangan pasir terhadap kecepatan aliran sungai}

Hasil pengamatan dan pengukuran terhadap kecepatan aliran sungai Asahan dalam gambar 2.

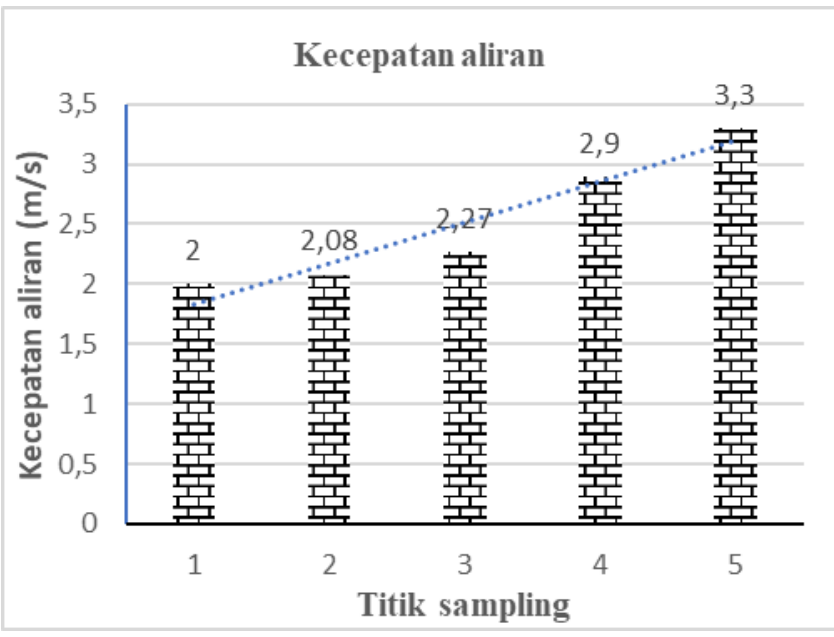

Gambar 2. Kecepatan aliran sungai Asahan pada titik sampling

Gambar 2 menunjukkan bahwa dari titik sampling 1 sampai 5 terjadi kenaikan kecepatan aliran sungai. Diduga, kenaikan kecepatan aliran ini disebabkan penambahan kecepatan aliran sungai ini disebabkan oleh perubahan profil sungai yang semakin mengecil akibat terjadinya proses sedimentasi

Data pengukuran kedalaman sungai menunjukkan bahwa pada titik sampling ke 3 sampai titik ke 5 terjad terjadi proses pendangkalan. Karena titik sampling ke 3 sampai ke 5 sudah melewati aktivitas penambangan, maka patut diduga bahwa proses sedimentasi ini dipengaruhi oleh aktivitas penambangan Pada titik 5 menjadi yang berada di paling hilir dan sudah melewati ke 2 area tambang, kecepatan aliran mencapai $3,3 \mathrm{~m} / \mathrm{s}$.

\subsection{Dampak pertambangan pasir terhadap debit sungai}

Hasil pengukuran dan perhitungan debit sungai Asahan pada titik sampling tertera pada gambar 3 .

Debit aliran suatu sungai dipengaruhi oleh luas penampang (profil) sungai dan kecepatan alirannya. Gambar 3 memperlihatkan bahwa debit sungai Asahan dari titik sampling 1 sampai titik sampling 5 mengalami kenaikan secara konsisten Kenaikan debit ini disebabkan karena dari titik 1 ke titik 5 terjadi pengecilan profil (tampang lintang) sungai. Proses pengecilan tampang 
lintang sungai secara signifikan dimulai pada titik ke 3 yang sudah melewati area pertambangan pasir. Begitu juga dengan kecepatan alirannya, naik secara signifikan pada titik sampling yang sama. Karena harus melewati tampang lintang sungai yang makin kecil, maka air sungai akan bergerak semakin cepat sehingga menyebabkan makin ke hilir debitnya semakin besar. Debit aliran yang terbesar ada pada titik 5 yaitu sebesar $512,5 \mathrm{~m}^{3} / \mathrm{s}$ yang terletak pada posisi paling hilir, sesudah melewati 2 lokasi pertambangan pasir. Dengan demikian dapat diduga bahwa aktivitas pertambangan pasir berkontribusi pada kenaikan debit aliran sungai

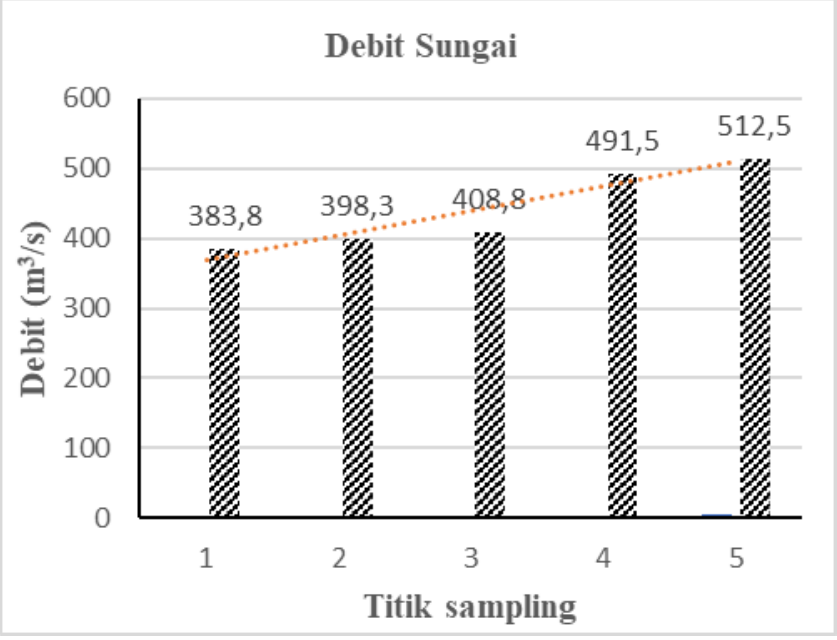

Gambar 3. Debit air sungai Asahan pada titik sampling

\subsection{Pengaruh pertambangan pasir terhadap sedimentasi sungai}

Menurut Asdak (2010) hasil sedimen tergantung pada besarnya erosi di DAS dan tergantung pada transport partikel tanah yang tererosi tersebut keluar dari daerah tangkapan air DAS. Produksi sedimen umumnya mengacu kepada besarnya laju sedimen yang mengalir melewati DAS. Tidak semua tanah yang tererosi di permukaan daerah tangkapan air akan sampai ke titik pengamatan. Sebagian tanah tererosi tersebut akan terdeposisi di cekungan-cekungan permukaan tanah dan bentuk penampang sedimen lainnya. Oleh karena itu, besarnya hasil sedimen biasanya bervariasi mengikuti karakteristik DAS

Kegiatan pertambangan pasir berpotensi menjadi salah satu penyebab tingginya konsentrasi sedimen di DAS Asahan yang berpengaruh pada bentuk profil sungai, kecepatan aliran, kedalaman sungai, lebar sungai, dan debit sungai. Gambar 4 menunjukkan hasil pengukuran sedimen pada titik sampling 1 sampai titik sampling ke 5.

Tampak pada gambar 4, mulai titik sampling 4 (yang terletak disebelah hilir penambangan 1 dan sebelah hulu penambangan 2) debit sedimennya bertambah cukup signifikan. Lonjakan penambahan debit sedimen terjadi pada titik sampling 5 yang berada pada hilir sungai yang sudah melewati 2 lokasi penambangan pasir. Dari fakta ini terlihat jelas bahawa aktivitas penambangan pasir memperbesar proses sedimentasi.

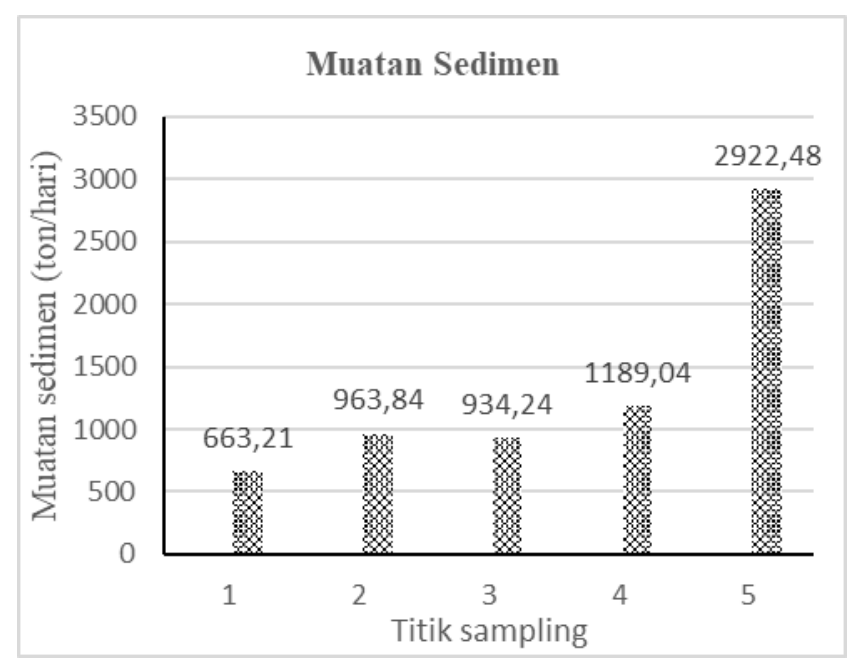

Gambar 4. Muatan sedimen

Menurut Asdak (2010), adanya aktivitas yang menyebabkan perubahan di daerah hulu DAS tidak hanya akan memberikan dampak di daerah berlangsungnya kegiatan tersebut. Aktivitas seperti ini akan berpengaruh dan menimbulkan dampak di daerah aliran sungai. Dampak yang ditimbulkan berupa perubahan fluktuasi debit yang semakin besar dan transport sedimen serta material yang terlarut dalam sistem aliran airnya yang semakin tinggi. Dalam jangka panjang, fluktuasi debit yang sangat tinggi akan akan mengakibatkani debit pada musim kemarau sangat kecil dan debit pada musim hujan sangat besar. Kondisi seperti Ini dapat menimbulkan masalah bagi masyarakat di sekitar DAS, misalnya tanah pertaniannya menjadi kekeringan pada musim kemarau dan terjadi banjir pada musim hujan. Data dari laporan Badan Penanggulangan Bencana Daerah pada tanggal 01 Mei 2020. DAS Asahan telah terjadi banjir. Hal ini terjadi dipicu oleh intensitas hujan yang tinggi dari hulu yang berasal dari kawasan pegunungan di Simalungun. Adapun desa yang terendam banjir yaitu Desa Bangun Sari di Kecamatan Setia Janji, Desa Rahuning I, di Kecamatan Rahuning, Desa Prapat Janji dan Desa Buntu Pane. Daerah lain yang terkena dampak adalah Kecamatan Buntu Pane, lalu Kecamatan Tinggi Raja lokasi yaitu Desa Terusan Tengah dan Desa Piasa Hulu

\section{Kesimpulan}

Berdasarkan hasil penelitian yang telah dilakukan sungai Asahan di Desa Tanjung Alam Kecamatan Sei Dadap Kabupaten Asahan Provinsi Sumatera Utara dapat disimpulkan sebagai berikut:

1. Pada daerah yang yang dekat dengan atau terdapat kegiatan penambangan pasir dengan menggunakan mesin sedot (titik sampling 2 sampai dengan titik sampling 5) mengalami peningkatan laju erosi dibanding titik sampling 1 yang berada jauh di arah hulu. Laju erosi terbesar terjadi pada titik sampling 5 yang berada 
di arah hilir ke 2 aktivitas penambangan dengan nilai sebesar 125,9 ton/ha/tahun. Laju erosi ini meningkat hampir 8 kali ipat dibanding laju erosi daerah hulu (titik sampling 1) yang belum terpengaruh aktivitas pertambangan yakni sebesar 16 ton/ha/tahun.

2. Laju erosi pada titik sampling 1 dan 2 dapat diklasifikasikan dalam kelas erosi ringan, pada titik sampling 3 dan 4 termasuk dalam kategori sedang, dan pada titik sampling 5 dalam kategori berat.

3. Keberadaan aktivitas penambangan pasir juga berpengaruh meningkatkan debit sedimen. Pada daerah hulu yang belum dipengaruhi aktivitas penambangan (titik sampling 1) debit sedimen hanya 663,21 ton/hari. Debit sedimen mulai bertambah pada titik sampling 2 yang berada pada arah hulu, dekat dengan aktivitas penambangan 1, debit sedimen sudah mulai terlihat naik, menjadi sebesar 791,5 ton/hari. Debit sedimen terbesar terjadi pada titik sampling 5 yang berada di arah hilir aktivitas penambangan 1 maupun 2 dengan nilai sebesar 2922,48 ton/hari. Nilai ini hampir 4 kali lipat dibanding debit sedimen pada daerah hulu yang belum terpengaruh aktivitas penambangan.

4. Sedimentasi pada titik sampling 1 dapat diklasifikasikan dalam kategori sedimentasi sedang, pada titik sampling 2 -5 termasuk dalam kategori sedimentasi jelek.

5. Aktivitas penambangan pasir memberikan pengaruh tinggi terhadap peningkatan laju erosi dan sedimentasi di sungai. Hal ini dibuktikan dengan hasil analisis dan perhitungan yang telah dilakukan disetiap titik sampling

\section{Saran}

Berdasar hasil pengamatan, maka dapat saran sebagai berikut:

1. Perlu dilakukan peningkatan upaya pengelolaan dari aktivitas pengambangan pasir dengan menggunakan mesin sedot terutama pada sisa air yang terbawa saat proses penyedotan yang langsung masuk ke dalam sungai.

2. Perlu dilakukan peningkatan upaya pengelolaan dan pemanfaatan lahan di sekitar pengambangan pasir agar dapat mengurangi tingkat laju erosi.

3. Perlunya meningkatkan peran serta masyarakat, pemerintah desa hingga provinsi untuk terus dapat mengawasi jalannya aktivitas penambangan pasir terutama dalam hal perizinan.

4. Bagi penelitian selanjutnya, diharapkan dapat melakukan analisis risiko terhadap parameter lainnya seperti kadar oksigen terlarut (DO), air tanah, penurunan jumlah flora fauna, penurunan tingkat kesehatan masyarakat, berkurangnya estetika lingkungan, dan sebagainnya

\section{Daftar Pustaka}

Anonim, 2008, Standar Nasional Indonesia, No. 3414, Badan Standardisasi Nasional.

Anonim, 2015, Standar Nasional Indonesia, No. 8066, Badan Standardisasi Nasional
Anonim, 2021, Sediment and Suspended Sediment, https://www.usgs.gov/special-topic/water-scienceschool/science/sediment-and-suspended-sediment?qtscience_center_objects $=0 \#$ \#t-science center_objects (20 Mei 2021)

Dyahwanti, I. N., 2007. Kajian dampak lingkungan kegiatan penambangan pasir pada daerah sabuk hijau Gunung Sumbing di Kabupaten Temanggung. Tesis. Sekolah Pascasarjana, Universitas Dipenogoro, Semarang.

Fatmawati. (2016). Analisis Sedimentasi Aliran Sungai Batang Sinamar Bagian Tengah Di Kenagarian Koto Tuo Kecamatan Harau Kabupaten Lima Puluh Kota Bukit Tinggi . Jurnal Geografi, 156164.

Junaidi, F. 2014. Analisis Distribusi Kecepatan Aliran Sungai Musi (ruas jembatan ampera sampai dengan pulau Kemaro). Jurnal Teknik Sipil dan Lingkungan. Vol.2 No.3 September 2014, ISSN: 2355-374x.

Kusumawardani, A. 2009. Daerah Aliran Sungai Asahan. Diambil dari Universitas Indonesia: staff.ui.ac.id/das_asahan_anggikusumawardhani.pdf.

Putra. 2014. Analisis Distribusi Kecepatan Aliran Sungai Musi (Ruas Sungai: Pulau Kemaro sampai dengan Muara Sungai Komering). Jurnal Teknik Sipil dan Lingkungan. Vol.2 No. 3 September 2014, ISSN: 2355-374x.

Sabrina, 2018. Kajian Sedimentasi pada Muara Sungai Batang Arau Kota Padang. Jurnal Ilmiah Rekayasa Sipil. Volume XV. Nomor 1, April 2018, eISSN: 2655-2124 / ISSN: 1858-3695.

Syarifudin, A., 2017, The influence of Musi river sedimentation to the aquatic environment, MATEC Web of Conferences 101, 04026

Sugiyono. 2013. Metode Penelitian Pendidikan Pendekatan Kuantitatif, Kualitatif, dan R\&D. Bandung: Alfabeta.

Suhartini. 2006. Mikrobiologi Industri. Yogyakarta: Andi.

Tamrin. 2018. Analisis Kegiatan Penambangan Pasir dan Batu Terhadap Erosi, Kualitas Air dan Sosial Ekonomi Masyarakat di Sekitar Sungai Indragiri Jurnal Photon. Vol. 8 No. 2, April 2018

Wardhana, W. 2004. Dampak Pencemaran Lingkungan. Yogyakarta: Andi. 